\title{
Testing the quality of film-based creative and innovative character education test with rasch model
}

\author{
Gendon Barus ${ }^{1}$, Juster Donal Sinaga ${ }^{2}$, Yustinus Dasilva Moron ${ }^{3}$ \\ ${ }^{123}$ Universitas Sanata Dharma, Indonesia
}

\section{Article Info \\ Article history: \\ Received Apr $10^{\text {th }}, 2019$ \\ Revised May 22 ${ }^{\text {nd }}, 2019$ \\ Accepted Jun $28^{\text {th }}, 2019$}

Keyword:
Character
Creative
Innovative
Validit
Reliability
Power difference; degree of
difficulty

Corresponding Author:

Juster Donal Sinaga

Email: donalsinaga@usd.ac.id

\begin{abstract}
This study aims to test the quality of Film-Based Creative and Innovative Character Education Test by examining the values of validity, reliability, different power, and level of difficulty. This study focuses on the Film-Based Creative and Innovative Character Education Outcomes Test using the 40 items Rasch Model. This research is a research development. Research subjects numbered 66 students in grade VII and VII of junior high school. Data analysis techniques to see the quality of test kits developed in this study using the Rasch Model with QUEST and Ministeps programs. The results showed: (1) the validity of the whole test items fit in the range of INFIT MNSQ $0.80-1.0$; (2) the reliability of the test questions is very high with a value of 0.92 ; (3) the level of difficulty of the midterm test items ( -1 to 1$)$ according to the Rasch Model category $(-2$ to +2$)$; and (4) the power of different test questions is in the good category. The conclusion of this research is that Film-Based Creative and Innovative Character Education Test Results can be used to measure the results of creative and innovative character education in schools.
\end{abstract}

\section{Pendahuluan}

Pendidikan karakter sangatlah penting bagi peserta didik di Indonesia. Sebagai upaya untuk meningkatkan kesesuaian dan mutu pendidikan karakter, kementrian pendidikan nasional mengembangkan grand design pendidikan karakter untuk setiap jalur dan jenjang pendidikan. Grand design tersebut menjadi rujukan konseptual dan pengembangan, pelaksanaan, dan penilaian pada setiap jalur dan jenjang pendidikan (Kemendiknas, 2010).

Tantangan bagi pemerintah dalam implementasi pendidikan karakter adalah belum tersedianya alat ukur untuk mengukur capaian siswa terhadap karakter yang dibentuk. Barus (2016) mengatakan bahwa untuk melakukan evaluasi dibutuhkan proses penilaian (asesmen) dan hasil tes. Untuk memperoleh hasil tes tentunya dibutuhkan suatu alat pendukung berupa alat tes atau alat ukur yang memadai agar dapat mengetahui sejauh mana pendidikan karakter sudah berjalan secara efektif di sekolah.

Perhatian pemerintah tentang alat tes penilaian karakter peserta didik masih minim. Hal itu nampak dari belum tersediannya model evaluasi yang digunakan untuk menilai pendidikan karakter peserta didik. Kalaupun ada, model evaluasi yang digunakan hanya mengukur sebatas pada skala sikap dan berhenti pada skala kognitif saja. Selama ini instrumen yang digunakan mengevalvuasi hasil pendidikan karakter antara lain observasi atau pengamatan, penilaian diri, tes (tanya jawab), dan diskusi (Supriyadi, 2011).

Penilaian menjadi permasalahan yang paling sering diperdebatkan dalam pendidikan karakter. Pendidikan karakter seringkali dianggap sebagai bidang yang sulit untuk diukur, dinilai, dan dievaluasi. Hal ini berkenaan dengan hasil akhir dari pendidikan karakter yang berupa tindakan moral, bukan berupa 
pemikiran atau gerakan yang dengan mudah dapat dinilai melalui kemampuan menulis jawaban dan mempraktikkan sebuah keterampilan yang kemudian diakumulasikan dalam bentuk angka. Masalah penilaian sering dikaitkan dengan tujuan pendidikan karakter. Apakah penilaian harus dikaitkan dengan kenaikan kelas atau kelulusan, seperti yang selama ini dianjurkan pemerintah. Jika ya, bagaimana teknik, instrumen, pelaksanaan, dan pemanfaatannya. Hal ini mengisyaratkan bahwa sistem pendidikan karakter di sekolah terutama pada aspek penilaian sangat mendesak untuk disempurnakan. Menurut Barus (2016) teknik-teknik penilian seperti ini memiliki kelemahan dan subjektifitas. Oleh karena itu perlu dikembangkan alat penilaian pendikdikan karakter yang lebih komprehensif dan memiliki daya jangkau pengukuran meliputi tiga domain, yaitu domain kognitif, afektif, dan juga psikomotorik pada siswa.

Terdapat sejumlah alat ukur pendidikan karakter dalam bentuk skala. Despriliani (2015) menggunakan alat ukur tes kreativitas untuk mengukur kreativitas siswa. Koyan (2014) mengembangkan alat ukur pendidikan karakter dan kepekaan moral dengan bentuk kuesioner. Triwati (2015) mengembangkan instrument pendidikan karakter juga dalam bentuk kuesioner.

Beberapa alat ukur yang dikembangkan tersebut menggunakan asumsi klasik untuk mengiji validitas, yaitu dengan membuat korelasi skor pada item itu yang diuji dengan skor total. Sebuah pertanyaan dikatakan valid apabila nilai koefisien korelasi $r=/>0,3$. Demikian juga reliabilitasnya dihitung menggunakan asumsi klasik. Salah satu teknik uji reliabilitas adalah Alpha Cronbach. Variabel dikatakan reliabel jika nilai Cronbach Alpha sebesar $a^{3} 0.60$ atau a ${ }^{3} 0.70$ (SPSS). Pada teknik yang lain seperti: SEM, LISREL, AMOS uji reliabilitas dilakukan dengan melihat nilai Construct Reliabity-nya.

Menurut Mardapi (2017) penggunaan teori tes klasik dalam menganalisis butir memiliki beberapa kelemahan diantaranya: statistik butir tes berupa tingkat kesukaran dan daya beda butir soal sangat tergantung kepada karakteristik peserta tes, estimasi kemampuan peserta tergantung kepada butir soal yang diujikan, estimasi skor kesalahan berlaku untuk semua peserta tes, tidak ada informasi tentang respon setiap peserta tes terhadap tiap butir soal, estimasi keandalan alat tes (reliabilitas) sangat tergantung pada data skor hasil tes. Dengan adanya kelemahan pada teori tes klasik tersebut, maka muncullah teori respon butir yang berusaha mengatasi kelemahan tersebut.

Salah satu teknik analisis validitas dan reliabilitas menggunakan pendekatan teori respon butir adalah Rasch Model. Menurut teori respon butir, perilaku seseorang dapat dijelaskan oleh karakteristik orang yang bersangkutan sampai pada batas-batas tertentu. Karakteristik tersebut disebut trait, dan seseorang dapat memiliki lebih dari satu trait. Setiap trait merupakan unjuk kerja dari orang yang bersangkutan. Setiap trait merupakan dimensi kemampuan seseorang. Validitas dan reliabilitas bagi suatu instrumen sangat penting untuk dipertahankan dan ditingkatkan sehingga instrumen tersebut terhindar dari kecacatan. Semakin tinggi nilai validitas dan reliabilitas suatu instrumen, maka akan semakin jitu data yang didapat dari suatu pengukuran. Wainer dan Braun (1998) menyatakan bahwa konsistensi suatu instrumen adalah apabila itemitem dalam suatu instrumen yang sama diuji beberapa kali kepada subyek atau responden yang sama atau hampir sama.

Tulisan ini bertujuan memaparkan hasil penelitian tentang pengujian kualitas Tes Hasil Pendidikan Karakter Kreatif dan Inovatif sebagai bagian dari proses pengembangan alat ukur pendidikan karakter kreatif dan inovatif berbasis film. Pengembangan alat ukur hasil pendidikan karakter ini tidak menggunakan pendekatan klasik tetapi teori respon butir Rasch Model. Kualitas alat ukur pendidikan karakter kreatif dan inovatif dalam penelitian ini yang dilihat melalui nilai validitas, reliabilitas, daya beda, dan tingkat kesulitan dianalisis menggunakan Rasch Model. Proses dan nilai masin-masing aspek kualitas alat ukur hasil pendidikan karakter kreatif dan inovatif akan duraikan dalam tulian ini.

Produk yang dikembangkan dan didesain dalam penelitian ini adalah Tes Hasil Pendidikan Karakter Kreatif dan Tes Karakter Inovatif Berbasis Film untuk mengukur hasil pendidikan karakter di sekolah. Tes ini memuat tayangan yang mengandung dilema moral, persoalan konflik moral, klarifikasi nilai yang menggambarkan karakter kreatif dan karakter inovatif yang mencerminkan tingkat pemahaman, (moral knowing), perasaan (moral afeksion), dan tindakan/prilaku (moral aksion) siswa diminta mengambil keputusan atas pertimbangan gradasi yang disediakan. Hal ini sejalan dengan pendapat Kustandi dan Sujipto, (2016) bahwa melalui film yang mengandung nilai-nilai positif dapat melengkapi pengalamanpengalaman dasar dari siswa; dapat mendorong dan meningkatkan motivasi serta menanamkan sikap dan segi-segi afektif dan mendukung pemikiran siswa. Soal tes ini terdiri dari 40 soal, masing-masing karakter mewakili 20 soal tes yang mengambarkan masing-masing dilema moral karakter. Bentuk soal tes hasil 
pendidikan karakter berbasis film bila dalam media film biasa disebut dengan video virtual. Karena selain menampilkan gamvar video, diakhir tayangan video juga ditampilkan pertanyaan dan jawaban.

Menurut Elkind dan Sweet (Fathurrohman, 2013) pendidikan karakter dimaknai sebagai usaha yang sungguh-sungguh membantu orang memahami, peduli, dan bertindak berdasarkan nilai-nilai etika. Sejalan dengan pendapat tersebut, Kevin Ryan dan Bohlin (Fathurrohman, 2013) berpendapat bahwa pendidikan karakter adalah upaya sungguh-sungguh untuk membantu seseorang memahami, peduli, dan bertindak dengan landasan nilai-nilai etis. Menurut Wibowo, (Prihana, 2017) pendidikan karakter memiliki esensi dan makna yang sama dengan pendidikan moral atau pendidikan akhlak. Pendidikan karakter mengandung beberapa aspek yaitu aspek pengetahuan (Cognitive), perasaan (afeksi), dan tindakan (action). Kementrian Pendidikan Nasional (2010), menjelaskan bahwa pendidikan karakter adalah usaha menanamkan kebiasaankebiasaan yang baik sehingga peserta didik mampu bersikap dan bertindak berdasarkan nilai-nilai yang telah menjadi kepribadiannya. Dari konsep-konsep tersebut pengertian pendidikan karakter dapat disimpulkan sebagai upaya untuk membantu individu agar dapat memahami, peduli dan bertindak sesuai dengan nilainilai inti etis (nilai-nilai karakter).

Salah satu karakter yang menjadi karakter yang dibangun melalui pendidikan karakter adalah karakter kreativitas. Kreativitas adalah sesuatu yang sangat kompleks, mempunyai banyak domain, dan muncul dalam beragam kehidupan manusia (Lucas, 2016). Kreativitas dianggap sebagai kemampuan intelektual manusia yang paling tinggi karena bersifat original dan unik (Abdulla \& Cramond, 2017). Kemampuan kreativitas ini juga digunakan sebagai landasan dasar yang berarah pada divergent thingking dan problem solving (Abdulla \& Cramond, 2017). Kreativitas juga berkaitan langsung dengan kemampuan individu dalam menghasilkan suatu performa belajar (Zhou, Shen, Wang, Neber, \& Johji, 2013). Dalam konteks pendidikan, kreativitas berfungsi untuk mengembangkan potensi dan keberadaan peserta didik yang diharapkan mampu mengoptimalkan kemampuan yang mereka miliki (Konstantinidou, Zisi, Katsarou, \& Michalopoulou, 2015). Kreativitas adalah tanggungjawab bersama, dimana setiap elemen dalam pendidikan haruslah secara positif dan aktif untuk menciptakan suasana pembelajaran dan pendidikan yang berbasis pada kekuatan kreativitas (Ramdani \& Fahmi, 2014). Kreativitas juga adalah indikator bahwa individu sekarang secara efektif mampu mengkolaborasikan pengetahuan dan nalar tertinggi mereka dalam bekerja (Delis et al., 2007). Dewasa ini juga penggunaan karakter kreativitas ini diperlukan untuk melakukan adaptasi terhadap perkembangan globalisasi yang menuntut kita untuk terus berpikir kreatif (Hromcová \& Agnese, 2018).

Selain karakter kreatif, karakter inovatif juga menjadi karakter yang dikembangkan pada siswa dalam pendidikan karakter. Inovasi adalah proses menemukan atau mengimplementasikan sesuatu yang baru ke dalam situasi yang baru. Kebaruan yang dimaksud dalam proses menemukan dan mengimplementasikan tersebut adalah memikirkan dan melakukan sesuatu yang baru, yang menambah atau menciptakan nilai atau manfaat sosial atau ekonomi (Raka, 2011). Untuk menghasilkan perilaku inovatif, seseorang harus melihat inovasi secara mendasar sebagai proses yang dapat dikelola (Adair, 1996)

Lebih lanjut Adair (1996) menjelaskan tiga hal perilaku inovatif, yaitu (1) generating ideas, yaitu individua atau kelompok menghasilkan gagasan untuk mengembangkan produk, proses, pelayanan yang ada sebelumnya atau menciptakan sesuatu yang baru; (2) harvesting ideas, yaitu proses mengumpulkan, menyaring dan mengevaluasi gagasan; (3) developing and implementing these idea, yaitu proses mengembangkan dan meningkatkan gagasan sampai pada diberikannya tanggapan yang berasal dari orang lain.

Ada sejumlah karakteristik individu yang memiliki perilaku inovatif, yaitu (1) memiliki visi yang jelas terhadap hasil yang akan dicapai, bahkan ketika mereka belum memiliki titik awal yang pasti bagaimana untuk mencapainya; (2) mendefinisikan sasaran yang spesifik dan mengambil manfaat dari kegiatan yang dilakukan; (3) mampu menghadirkan contoh, masalah atau wujud nyata ide untuk membujuk dengan rasional; (4) mendapatkan dukungan dan mampu membangun kelompok dengan tujuan yang sama, sehingga semua orang merasa mereka itu partner dalam kegiatan; (5) berani dan mampu mengambil resiko yang telah diperhitungkan dan menghadapi kesulitan atau hambatan; (6) mampu memotivasi dan menginspirasi orang dalam melakukan kegiatan sehingga setiap orang memberikan kontribusi yang penuh terhadap kegiatan dan berpartisipasi dalam setiap keputusan; (7) mampu mempengaruhi untukk menggerakkan dukungan dan sumber daya yang ada agar kegiatan berjalan; (8) mampu mengatasi hambatan dengan baik terhadap setiap campur tangan dan oposisi; (9) memiliki ketekunan menjaga momentum setelah 
adanya penurunan antusiasme anggota kelompok; dan (10) mampu meyakinkan seluruh anggota kelompok agar terlibat secara penuh dan adil dalam setiap penghargaan yang diberikan (Adair, 1996.)

Penilaian (asesmen) adalah suatu proses untuk mengatahui apakah proses dan hasil dari suatu program kegiatan telah sesuai dengan tujuan atau kriteria yang telah ditetapkan (Suwandi, 2010). Penilaian (asesmen) juga dipahami sebagai suatu prosedur sistematis dan mencakup kegiatan mengumpulkan, menganalisis, serta menginterpretasikan informasi yang dapat digunakan untuk membuat kesimpulan tentang karakteristik seseorang atau objek (Suprananto dan Kusaeri, 2013). Dalam konteks pendidikan, penilaian dipandang sebagai suatu proses yang sistemis dan mencakup kegiatan mengumpulkan, menganalisis, serta menginterpretasikan informasi untuk menentukan seberapa jauh seorang siswa atau sekelompok siswa mencapai tujuan pembelajaran yang telah ditetapkan, baik aspek pengetahuan, sikap maupun keretampilan. Dari pendapat para ahli di atas maka dapat ditarik kesimpulan bahwa penilaian (asesmen) merupakan suatu proses yang sistematis dan mencakup kegiatan mengumpulkan, menganalisis, serta menginterpretasi informasi untuk mengatahui apakah proses dan hasil dari suatu program kegiatan telah sesuai dengan tujuan atau kriteria yang telah ditetapkan. Dimana penilaian (asesmen) tidak terpisah dari proses pengukuran.

Dalam menggunakan asesmen di kelas ada beberapa prinsip yang perlu diperhatian (Suwandi, 2010), yaitu : (1) valid (penilaian berbasis kelas harus mengukur apa yang seharusnya diukur dengan menggunakan alat yang dapat dipercaya dan sah); (2) mendidik (penilaian harus memberi sumbangan yang positif terhadap hasil pencapaian belajar siswa : dirasakan sebagai penghargaan yang memotivasi bagi siswa yang berhasil dan sebagai pemicu semangat untuk meningkatkan hasil belajar bagi yang kurang berhasil); (3) berorientasi pada kompetisi (mampu menilai pencapaian kompetensi yang dimaksud dalam kurikulum); (4) adil dan objektif (Penilaian harus adil terhadap semua siswa dan tidak membeda-bedakan latar belakang siswa); (5) terbuka (kriteria penilaian hendaknya terbuka bagi berbagai kalangan sehingga keputusan tentang keberhasilan siswa jelas bagi pihak-pihak yang berkepentingan); (6) berkesinambungan (penilaian dilakukan secara terencana, bertahap, teratur terus menerus, dan berkesinambungan untuk memperoleh gambaran tentang perkembangan kemajuan belajar siswa); (7) menyeluruh (penilaian terhadap hasil belajar siswa hendaknya dilaksanakan secara menyeluruh, utuh, dan tuntas yang mencakup aspek kognitif, afektif, dan psikomotorik serta berdasarkan berbagai teknik dan prosedur penilaian dengan berbagai bukti hasil belajar siswa); dan (8) bermakna (penilaian hendaknya mudah dipahami dan mudah ditindak lanjut oleh pihakpihak yang berkepentingan).

Menurut Azwar (2014) awal kerja penyusunan atau pengembangan suatu alat tes dimulai dari: (1) Identifikasi tujuan ukur, yaitu memilih suatu definisi, mengenali dan memahami dengan seksama teori yang mendasari konstruk atribut yang hendak diukur; (2) Pembatasan domain ukur yang dilakukan dengan cara menguraikan konstruk teoretik atribut yang diukur menjadi beberapa rumusan demensi atau aspek yang lebih jelas, agar menunjang validitas isi skala; (3) Oprasionalisasi aspek. Oprasionalisasi aspek diperlukan untuk membentuk keprilakuan yang hendak diukur dapat lebih konkret sehingga penulis item akan lebih memahami benar arah respon yang harus diungkap dari subjek; (4) Penulisan item. Item dibuat dalam jumlah yang lebih banyak yaitu sekitar tiga kali lipat dari jumlah item yang digunakan dalam bentuk final, untuk menghindari kehabisan item akibat gugurnya item-iten yang tidak memenuhi syarat; (5) Review penulisan item, yaitu mengecek ulang setiap item apakah telah sesuai dengan indikator prilaku yang hendak diungkap. Semua item yang tidak sesuai dengan kaidah atau spesifikasi blue print harus diperbaiki, dan hanya item-item yang diyakini berfungsi dengan baik oleh ahli (expert judgmen), yang dapat diloloskan untuk uji empiric; (6) Uji coba bahasa (evaluasi kualitatif). Kumpulan item yang telah direviu kemudian dievaluasi secara kualitatif, dengan mengujicobakan pada sekelompok kecil responden untuk mengetahui apakah kalimat yang digunakan sudah tepat dan mudah dipahami oleh responden sesuai dengan apa yang diinginkan oleh penulis item; (7) Field tes (evaluasi kuantitatif). Evaluasi kuantitatif atau analisis item merupakan proses pengujian item secara kuantitatif guna mengetahui apakah item memenuhi syarat psikometrik untuk disertakan sebagai bagian dari skala. Parameter item yang diuji adalah daya beda item atau daya diskriminasi item; (8) Seleksi item. Item-item diseleksi sesuai dengan syarat psikometri. Item-item yang memenuhi syarat psikometrik digunakan dalam skala; (9) Validasi konstruk, yaitu proses yang berkelanjutan melalui validasi isi kemudian dilanjutkan dengan uji empiric; (10) Kompilasi final, yaitu perakitan skala secara final dengan memperhatikan tampilan yang menarik namun tetap memudahkan responden untuk membaca dan menjawabnya serta dilengkapi dengan petunjuk soal dan lembar jawab.

Karakter kreatif dan inovatif adalah dua krakter yang dikembangkan pada para siswa melalui pendidikan karakter. Untuk mengetahui capaian pendidikan karakter kreatif dan inovatif dikembangkan alat ukur 
pendidikan karakter berbasis film. Alat ukur tersebut kemudian dianalisis kualitasnya menggunakan Rasch Model. Rasch Model dikembangkan oleh Georg Rasch. Menurut Sumintono \& Widhiarso, (2013) Rasch Model merupakan suatu model yang berasal dari teori respon butir atau Item Respon Theory (IRT). Georg Rasch mengembangkan satu model analisis dari teori respon butir atau Item Response Theory pada tahun 1960-an, dengan data mentah berupa data dikotomi (berupa benar dan salah) yang mengindikasikan kemampuan responden.

Analisis dengan Rasch Model menghasilkan analisis statistik kesesuaian (fit statistics) yang memberikan informasi pada peneliti apakah data yang didapatkan memang secara ideal menggambarkan bahwa orang yang mempunyai abilitas tinggi memberikan pola jawaban terhadap item sesuai dengan tingkat kesulitannya. Parameter yang digunakan adalah infit dan outfit dari kuadrat tengah (mean square) dan nilai terstandarkan (standardized values). Menurut Sumintono dan Widhiarso, (2013) infit (inlier sensitive atau information weighted fit) adalah kesensitifan pola respon terhadap item sasaran pada responden (person) atau sebaliknya; sedangkan outfit (outlier sensitive fit) mengukur kesensitifan pola respon terhadap item dengan tingkat kesulitan tertentu pada responden atau sebaliknya.

Searing (2018) menjelaskan bahwa Rasch Model merupakan suatu model pengukuran yang terbentuk berdasarkan hasil pertimbangan validitas dan reliabilitas setiap calon responden yang menjawab soal dan kesukaran soal bagi setiap soal. Dalam pengukuran Rasch Model, validitas dan reliabilitas suatu instrumen dapat diketahui dengan melihat analisa-analisa seperti item polarity, unidimensional, pemetaan itemindividu/responden, reliabilitas item-individu, dan beberapa bentuk analisa yang lainnya (Bond \& Fox, 2007). Menurut Aziz (2015) Rasch Model adalah satu teknik analisis alat ukur penelitian menggunakan program berbasis komputer. Sudah banyak penelitian pengembangan alat ukur menggunakan model ini, diantaranya penelitian yang dilakukan oleh Phillipson (2008) untuk mengukur prestasi, penelitian tentang harga diri yang dilakukan oleh Widhiarso (2013), penelitian yang dilakukan oleh Stephens (2014) tentang menguji kepuasan siswa terhadap layanan akademik, serta penelitian yang dilakukan oleh Maat (2015) yang menggunakan model Rasch dalam mengukur tes matematika.

Menurut Suryani (2018) konsep pengukuran objektif dalam ilmu sosial dan penilaian pendidikan harus memiliki lima kriteria: 1) Memberikan ukuran yang linier dengan interval yang sama; 2) Melakukan proses estimasi yang tepat; 3) Menemukan item yang tidak tepat (misfits) atau tidak umum (outlier); 4) Mengatasi data yang hilang; 5) Hasilkan pengukuran yang replicable (independen dari parameter yang diteliti). Kelima kondisi pengukuran ini, sejauh ini hanya Rasch Model yang bisa memenuhinya. Melalui analisis Rasch Model diharapkan kualitas pengukuran yang dilakukan akan mempunyai kualitas yang sama seperti halnya pengukuran yang dilakukan dalam dimensi fisik dalam bidang fisika.

Analisis pengukuran menggunakan Rasch Model akan menghasilkan analisis statistik kesesuaian (fit statistics) yang memberikan informasi pada peneliti apakah data yang didapatkan memang secara ideal menggambarkan bahwa orang yang mempunyai abilitas tinggi memberikan pola jawaban terhadap aitem sesuai dengan ingkat kesulitannya. Hasil pengukuran yang menggunakan Rasch model bisa memenuhi ketiga elemen penting dalam pengukuran. Selain itu, uji kuantitatif instrument yang dilakukan dengan Rasch Model tidak hanya mengukur indeks realibilitas tetapi analisis item dilakukan ke tingkat masing-masing item. Selain terhadap item, Rasch model juga secara bersamaan menguji person (responden), dimana akan terlihat pola jawaban responden yang konsisten, maupun mengidentifikasi jawaban yang asal saja melainkan juga untuk menguji dimensionalitas dan deteksi adanya bias dari aitem pada instrumen inteligensi.

\section{Metode}

Penelitian ini merupakan penelitian pengembangan alat pengukuran hasil pendidikan karakter kreatif dan inovatif berbasis film dengan menggunakan Model Rasch. Tes yang dikembangkan adalah Tes Karakter Kreatif dan Karakter Inovatif berbasis film. Tes ini berupa film karakter kreatif dan inovatif yang memuat dilemma moral. Film karakter kemudian diikuti oleh pernyataan dan jawaban berupa pilihan berganda (multiple choice) dengan menggunakan skala jenjang. Jumlah soal tes ini adalah 20 butir. Metode pengumpulan data yang digunakan dalam penelitian ini adalah dengan menggunakan metode survey. Data dalam penelitian ini diperoleh dari 66 siswa SMP. Teknik analisis data yang digunakan untuk mengetahui kualitas (validitas, reliabilitas, tingkat kesukaran, dan daya beda) adalah Model Rasch dengan menggunakan program Winsteps. Dalam model pengukuran Rasch dengan bantuan program QUEST dan Ministep, validitas dan reliabilitas suatu instrumen dapat diketahui dengan melihat analisa-analisa seperti item polarity, unidimensial, pemetaan item-individu/responden, reliabilitas item, dan beberapa bentuk analisa 
yang lainnya. Sehubungan dengan itu, penelitian ini dilakukan untuk mendapatkan bukti secara empirik tentang validitas dan reliabilitas soal tes karakter kreatif dan inovatif berupa data politomi, menggunakan pengukuran Model Rasch. Adapun formula Model Rasch dengan program QUEST dan Ministeps adalah sebagai berikut:

$$
\operatorname{Pni1}(x=1 / \beta n, \delta i, F)=\frac{e(\beta-[\delta+F])}{1+e(\beta-[\delta i+F 1])}
$$

\section{Hasil dan Pembahasan}

Hasil penelitian ini mengungkap kualitas Soal Tes Pendidikan Karakter Kreatif dan Karakter Inovatif Berbasis Film baik. Hal ini diketahui dari nilai-nilai dari koefisien validitas, reliabilitas, daya beda, dan tingkat kesulitan. Uji validitas menurut Rasch Model ditentukan oleh kriteria yaitu INFIT MNSQ (0,77 sampai dengan 1,30). Berdasarkan hasil analisis data diketahui bahwa seluruh item Tes Hasil Pendidikan Karakter Kreatif Berbasis Film memenuhi kriteria validitas dengan INFIT MNSQ antara 0,89 sampai dengan 1,14. Demikian juga item Tes Hasil Pendidika Karakter Inovatif Berbasis Film memenuhi kriteria validitas dengan INFIT MNSQ antara 0,85 sampai dengan 1,21.

Sementara itu, nilai reliabilitas Tes Hasil Pendidika Karakter Kreatif dan Inovatif berbasis Film dalam penelitian ini ditetapkan berdasarkan nilai reliability item (Subali, 2011). Berdasarkan perhitungan menggunakan Rasch Model, diperoleh hasil yang sama dengan nilai koefisien reliabilitas sebesar 0.92 untuk itu Soal Tes Karakter Kreatif dan Soal Tes Karakter Inovatif. Berdasarkan kategori Rasch Model dapat diketahui bahwa reliabilitas item termasuk dalam kategori bagus sekali.

Setelah menghitung nilai reliabilitas tes kemudian dihitung tingkat kesulitan Tes Hasil Pendidikan Karakter Kreatif dan Inovatif diketahui melalui Item Estimates (Thresholds) dengan kriteria nilai -2,0 sampai dengan 2,0. Berdasarkan hasil analisis ditemuka 19 item Tes Hasil Pendidika Karakter Kreatif memiliki tingkat kesulitan antara 0,0 sampai dengan 1,0. Bila dilihat dari kategori tingkat kesulitan maka item-item tersebut tergolong sedang, dan cocok untuk digunakan untuk mengukur hasil pendidikan karakter kreatif. Hasil analisis data juga menemukan 1 item Tes Hasil Pendidika Karakter Kreatif dengan degradasi pilihan yang sukar yaitu item nomor 6 dengan skor 4. Berdasarkan data ini item nomor 6 memiliki nilai tingkat kesulitan sebesar 2.44. Bila dilihat dari kategori tingkat kesulitan maka item tersebut tergolong sulit dan tidak cocok untuk digunakan untuk mengukur karakter kreatif siswa karena item tersebut tidak dapat digunakan untuk membedakan mana siswa yang berkarakter kreatif maupun siswa yang berkarakter kurang kreatif.

Pada Tes Hasil Pendidikan Karakter Inovatif ditemukan 19 item yang memiliki tingkat kesulitan diantara 0,0 sampai dengan 1,5 kategori sedang, dan 1 item yang memiliki tingkat kesulitan lemah. 19 item yang memiliki tingkat kesulitan sedang cocok untuk digunakan untuk mengukur hasil pendidikan karakter inovatif siswa, sementara 1 item yang memiliki tingkat kesulitan lemah dengan nilai tingkat kesulitan sebesar -2.72 tidak cocok untuk digunakan dalam mengukur karakter inovatif siswa, karena tidak dapat membedakan mana siswa yang berkarakter inovatif maupun siswa yang berkarakter kurang inovatif.

Selain nilai validitas, reliabilitas, tingkat kesulitan, penelitian ini juga menganalisis nilai daya beda butir soal baik untuk Tes Hasil Pendidikan Karakter Kreatif mapun Tes Hasil Pendidikan Karakter Inovatif. Antara tingkat kesulitan dan daya beda dalam Rasch Model memiliki keterkaitan, dilihat dari tingkat kesulitan item yang memiliki tingkat kesulitan tinggi, sedang, dan rendah, maka item-item Tes Hasil Pendidikan Karakter Kreatif dan Inovatif menunjukan daya beda yang jelas yakni antara tiap gradasi pilihan menunjukan skor yang berbeda mulai dari skor 1 sampai skor 4 memiliki nilai daya beda skor item. Selain itu untuk melihat daya beda kemampuan siswa dapat dilihat pada gambar tingkat kesulitan, yang juga menggambarkan daya beda kemampuan siswa dalam menjawab soal tes.

Bila dilihat dari hasil validitas, reliabilitas, daya beda dan tingkat kesulitan maka item Tes Hasil Pendidikan Karakter Kreatif Berbasis Film yang dikembangkan dalam penelitian ini memiliki kualitas yang baik atau memadai untuk digunakan sebagai alat tes untuk menilai hasil pendidikan karakter siswa di SMP. Data kualitas Tes Hasil Pendidikan Karakter Kreatif meliputi nilai validitas, reliabilitas, tingkat kesukaran, dan daya beda butir tampak pada tabel berikut. 
Tabel 1 Rekapitulasi Hasil Hitung Validitas, Reliabilitas, Tingkat Kesulitan, dan Daya Beda Soal Tes Karakter Kreatif

\begin{tabular}{|c|c|c|c|c|c|c|c|c|}
\hline \multirow[t]{2}{*}{ Nama Tes } & \multirow[t]{2}{*}{ No item } & \multirow[t]{2}{*}{ Validitas } & \multirow[t]{2}{*}{ Reliabilitas } & \multirow{2}{*}{$\begin{array}{c}\text { Tingkat } \\
\text { Kesulitan }\end{array}$} & \multicolumn{4}{|c|}{ Daya Beda } \\
\hline & & & & & 1 & 2 & 3 & 4 \\
\hline \multirow{20}{*}{ 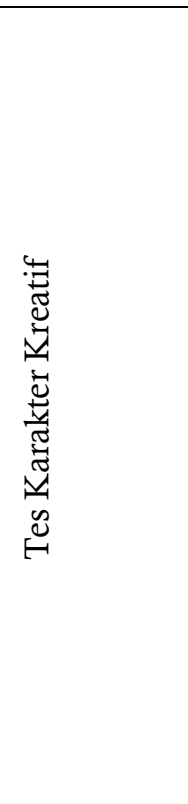 } & 1 & 1.00 & .92 & Sedang & -.10 & -.38 & .23 & .16 \\
\hline & 2 & .94 & & Sedang & NA & NA & -.37 & .37 \\
\hline & 3 & 1.11 & & Sedang & .01 & .06 & .12 & -.13 \\
\hline & 4 & .99 & & Sedang & -.12 & -.19 & .04 & .13 \\
\hline & 5 & 1.03 & & Sedang & -.29 & .14 & -.03 & .23 \\
\hline & 6 & 1.01 & & Tinggi & -.33 & .16 & .05 & .01 \\
\hline & 7 & .89 & & Sedang & -.44 & .07 & -.26 & .44 \\
\hline & 8 & 1.04 & & Sedang & -.07 & -.21 & .11 & -.01 \\
\hline & 9 & .98 & & Sedang & -.26 & -.12 & -.18 & .37 \\
\hline & 10 & 1.06 & & Sedang & NA & NA & .10 & -.10 \\
\hline & 11 & 1.14 & & Sedang & .11 & NA & -.26 & .11 \\
\hline & 12 & 1.02 & & Sedang & -.17 & -.10 & .18 & .27 \\
\hline & 13 & .98 & & Sedang & -.29 & -.07 & .03 & .22 \\
\hline & 14 & .97 & & Sedang & NA & NA & -.25 & .25 \\
\hline & 15 & .90 & & Sedang & -.38 & -.14 & -.08 & .35 \\
\hline & 16 & 1.10 & & Sedang & -.06 & -.13 & .08 & .11 \\
\hline & 17 & 1.00 & & Sedang & -.39 & .11 & .06 & .26 \\
\hline & 18 & .96 & & Sedang & -.13 & -.24 & -.12 & .30 \\
\hline & 19 & .91 & & Sedang & -.34 & NA & .02 & .23 \\
\hline & 20 & .95 & & Sedang & -.26 & -.12 & -.08 & .30 \\
\hline Nama Tes & No item & Validitas & Reliabilitas & $\begin{array}{c}\text { Tingkat } \\
\text { Kesulitan }\end{array}$ & $\begin{array}{l}\text { Daya } \\
\text { Beda }\end{array}$ & $\begin{array}{c}\text { Nama } \\
\text { Tes }\end{array}$ & $\begin{array}{c}\text { No } \\
\text { item }\end{array}$ & Validitas \\
\hline \multirow{20}{*}{ 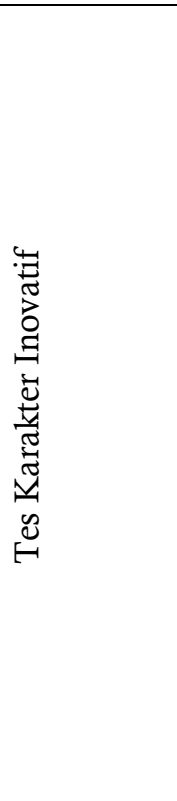 } & 1 & 1.00 & .92 & Sedang & -.25 & NA & .03 & .12 \\
\hline & 2 & .87 & & Sedang & -.55 & .06 & .20 & 29 \\
\hline & 3 & 1.01 & & Sedang & -.09 & -.17 & .11 & .05 \\
\hline & 4 & 1.07 & & Rendah & -.10 & -.06 & .00 & .11 \\
\hline & 5 & 1.01 & & Sedang & -.17 & -.05 & -.19 & .28 \\
\hline & 6 & 1.21 & & Sedang & -.15 & -.04 & .05 & .14 \\
\hline & 7 & .93 & & Sedang & -.08 & -.37 & .01 & .38 \\
\hline & 8 & 1.08 & & Sedang & .02 & -.17 & .10 & .00 \\
\hline & 9 & 1.03 & & Sedang & -.17 & -.09 & -.06 & .24 \\
\hline & 10 & .91 & & Sedang & -.42 & -.16 & .08 & .42 \\
\hline & 11 & .85 & & Sedang & -.16 & -.49 & .08 & .47 \\
\hline & 12 & .90 & & Sedang & -.54 & .09 & .00 & .28 \\
\hline & 13 & .87 & & Sedang & -.31 & NA & -.33 & .42 \\
\hline & 14 & 1.18 & & Sedang & .05 & -.18 & -.18 & .22 \\
\hline & 15 & 1.03 & & Sedang & -.23 & .02 & -.20 & .29 \\
\hline & 16 & 1.03 & & Sedang & -.23 & -.19 & -.12 & .40 \\
\hline & 17 & .94 & & Sedang & -.32 & -.05 & -.10 & .33 \\
\hline & 18 & 1.06 & & Sedang & -.15 & -.10 & -.13 & .25 \\
\hline & 1 & 1.00 & & Sedang & -.25 & NA & .03 & .12 \\
\hline & 2 & .87 & & Sedang & -.55 & .06 & .20 & .29 \\
\hline
\end{tabular}

Berdasarkan Tabel 1, Tes Hasil Pendidikan Karakter Kreatif Berbasis Film memiliki kualitas yang memadai sebagai alat ukur. Kualitas tersebut tergambar dari perolehan nilai validitas konstruk, reliabilitas, tingkat kesulitan, dan daya beda oleh masing-masing tes. Dari hasil uji kualitas item Tes Hasil Pendidikan Karakter Kreatif diketahui bahwa seluruh item memiliki nilai fit, artinya semua item soal dalam posisi valid. Dengan menggunakan item response theory (IRT) Rasch Model, peneliti menggunakan patokan INFIT MNSQ dimana menurut Adam \& Khoo (Subali, 2011) suatu item dinyatakan fit/valid dengan model bila batas kisaran INFIT MNSQ dari 0,77 sampai 1,30. Hasil hitung validitas seluruh item berada pada nilai 0,85 sampai dengan 1,21 untuk karakter kreatif, dan 0,89 sampai dengan 1,14 untuk karakter inovatif. Nilai 
tersebut menggambarkan bahwa seluruh item Tes Hasil Pendidikan Karakter Kreatif seluruhnya berada dalam posisi fit dengan model. Dengan demikian Tes Hasil Pendidikan Karakter Kreatif Berbasis Film mampu mengukur hasil pendidikan karakter kreatif dan inovatif di sekolah. Hal ini sejalan dengan pandangan Allen dan Yen (1979) yang menyatakan bahwa validitas dari suatu perangkat tes dapat diartikan merupakan kemampuan suatu tes untuk mengukur apa yangseharusnya diukur. Validitas menjadi salah satu kriteria untuk mengetahui sebuah alat ukur itu baik atau tidak (Arifin, 2017).

Selain nilai validitas, nilai reliabilitas menjadi salah satu kriteria untuk mengetahui kualitas suatu alat ukur. Penelitian ini menemukan bahwa nilai reliabilitas Tes Karakter Kreatif dan Tes Karakter Inovatif Berbasis Film memiliki nilai 0,92. Nilai reliablitas Tes Karakter Kreatif dan Tes Karakter Inovatif Berbasis Film sebesar 0.92 menunjukkan tes tersebut memiliki korelasi atau reliabel yang tinggi (Basuki dan Haryanto, 2014). Subali (2011) mengatakan bahwa dalam Rasch Model, semakin tinggi nilai reliabilitas semakin banyak item yang fit dengan model dan semakin meyakinkan bahwa pengukuran memberikan hasil yang konsisten. Linacre (2006) mengatakan bahwa nilai reliabilitas item antara 0.67 hingga 0.80 dikategorikan sederhana, 0.81 hingga 0.90 dikategorikan baik, dan $>0.91$ sangat baik. Sedangkan, indeks reliabilitas item dan responden yang diterima adalah $\geq 0.8$ (Bond dan Fox 2007).

Tingkat kesulitasn tes adalah kriteria yang lain dari sebuah alat ukur yang baik. Berdasarkan hasil penelitian sebagian besar item Tes Hasil Pendidikan Karakter Kreatif memiliki tingkat kesulitan sedang. Pada Tes Hasil Pendidikan Karakter Kreatif hanya ada 1 item yang memiliki tingkat kesulitan sangat tinggi sehingga tidak cocok untuk digunakan untuk mengukur hasil pendidikan karakter. Demikian juga Tes Hasil Pendidikan Karakter Inovatif terdapat 1 item yang memiliki tingkat kesulitan redah sehingga tidak cocok digunakan untuk hasil pendidikan karakter.

Selain nilai validitas, reliabilitas, tingkat kesulitan, penelitian ini juga menganalisis nilai daya beda butir soal baik untuk Tes Hasil Pendidikan Karakter Kreatif mapun Tes Hasil Pendidikan Inovatif. Antara tingkat kesulitan dan daya beda dalam Rasch Model memiliki keterkaitan, dilihat dari tingkat kesulitan item yang memiliki tingkat kesulitan tinggi, sedang, dan rendah, maka item-item Tes karakter Kreatif dan Tes Karakter Inovatif menunjukan daya beda yang jelas yakni antara tiap gradasi pilihan menunjukan skor yang berbeda mulai dari skor 1 sampai skor 4 memiliki nilai daya beda skor item. Selain itu untuk melihat daya beda kemampuan siswa dapat dilihat pada gambar tingkat kesulitan, yang juga menggambarkan daya beda kemampuan siswa dalam menjawab soal tes.

Berdasarkan temuan dan pembahasan penelitian dapat disimpulkan bahawa kulitas Tes Hasil Pendidikan Karakter Kreatif dan Inovatif berbasis Film ditinjau dari validitas, reliabilitas, daya beda dan tingkat kesulitan memiliki kualitas yang baik atau memadai untuk digunakan sebagai alat tes untuk menilai hasil pendidikan karakter siswa di SMP. Hal ini sejalan dengan temuan Heryanto (2018) yang menyatakan bahwa setidaknya penilaian sebagai produk harus berbasiskan fakta data yang validitas dan reliabilitasnya bisa dipertanggungjawabkan. Dalam hal ini kualitas Tes Hasil Pendidikan Karakter Kreatif dan Inovatif suda berbasis fakta data tidak hanya validitas dan reliabilitas, tetapi juga nilai daya beda dan tingkat kesulitan.

\section{Kesimpulan}

Hasil analisis data Tes karakter Kreatif dan Tes Karakter Inovatif Berbasis Film yang dikembangkan dapat dijadikan sebagai dukungan empirik untuk menyatakan bahwa Tes karakter Kreatif dan Tes Karakter Inovatif ini memiliki jaminan psikometris yang bagus. Hal ini dapat dilihat pada nilai validitas yang menunjukkkan semua item valid. Selain itu, nilai validitas Tes karakter Kreatif dan Tes Karakter Inovatif juga menjadi jaminan psikometris yang baik ditunjukkan oleh nilai reliabilitas mencapai 0,92. Dua kriteria lain yang menunjukkan kualitas Tes karakter Kreatif dan Tes Karakter Inovatif Berbasis Film baik adalah nilai tingkat kesulitasn item dan daya beda yang sudah terkoreksi dengan baik.

\section{Referensi}

Abdulla, A. M., \& Cramond, B. (2017). "After six decades of systematic study of creativity: What do teachers need to know about what it is and how it is measured?" Roeper Review, 39(1), pp. 9-23. https://doi.org/10.1080/02783193.2016.1247398.

Adair, J. (1996). Effective Innovation: How to Stay Ahead of the Competition. London: Pan Books

Allen, M.j., \& Yen, W.M. (1979). Introduction to measurement theory. Monterey, Mexico: Brooks/Cole Publishing Company. 
Aziz, Rahmat. (2015). "Aplikasi Model Rasch dalam Pengujian Alat Ukur Kesehatan Mental di Tempat Kerja”. Psikoislamika. Jurnal Psikologi Islam (JPI), Vol. 2 (2), hal. 1-16.

Azwar, Saifuddin. (2014). Penyusunan skala psikologi (edisi 2). Yogyakarta: Pustaka Pelajar.

Arifin, Zaenal (2017). "Kriteria Instrumen dalam suatu Penelitian". Jurnal THEOREMS (The Original Research of Mathematics) Vol. 2(1), hal. 28-36.

Basuki, I., \& Hariyanto. (2014). Asesemen pembelajaran. Bandung: PT. Remaja Rosdakarya

Barus, Gendon., M.M. Sri Hastuti., Juster Donal Sinaga. (2016). Bimbinggan klasikal nuansa pendidikan karakter SMP kelas IX. Yogyakarta: Sanata Dharma University Press.

Bond, T.G. \& Fox, C.M. (2007). Applying the Rasch model: Fundamental measurement in the human sciences. Ed. Ke-2. New Jersey: Lawrence Erlbaum Associates Publishers London.

Delis et al., (2001).D.C. Delis, E. Kaplan, J.H. Kramer. Delis-kaplan executive function system (D-KEFS). The Psychological Corporation: San Antonio.

Despriliani, Ririn. (...). Analisis Psikometri Instrumen Pengukuran Kreativitas Dengan Skala Pengukuran Kreativitas Utami Munandar. Jurnal Psikologi.

Djemari, M. (2017). Penilaian Pendidikan Karakter, Bahan Tulisan Pendidikan Karakter Universitas Negeri Yogyakarta, http://staff.uny.ac.id/ Sites/default/tmp/ Penilaian karakter.pdf. (Diakses 19-10-2019).

Fahmi, Irfan dan Zulmi Ramdani. (2014). Profil Kekuatan Karakter Dan Kebajikan Pada Mahasiswa Berprestasi. Psympathic, Jurnal Ilmiah Psikologi, Vol. 1 (1), hal. 98-108.

Fathurrohman, Pupuh., AA Suryana., Fenny Fitriani. (2013). Pengembangan pendidikan karakter. Bandung: PT Refika Aditama.

Heryanto. (2018). Model Penilaian Hasil Belajar dan Karakter. Naturalistic: Jurnal Kajian Penelitan Pendidikan dan Pembelajaran, No. 2 (2), hal. 118-128.

Hromcová, J., \& Agnese, P. (2018). "Globalization, welfare, and the attitudes toward higher education". Economic Modelling, November 2018, page. 1-15. https://doi.org/10.1016/j.econmod.2018.05.013.

Kemendiknas. (2010). Peraturan Pemerintah Nomor 17 Pasal 17 Ayat 3 Tahun 2010, Tentang Pengelolaan Penyelenggaraan Pendidikan.

Koyan, I Wayan (2014). "Pengembangkan Alat Ukur Pendidikan Karakter Dan Kepekaan Moral Para Mahasiswa STKIP Citra Bakti Ngada”. Jurnal Ilmiah Pendidikan Citra Bakti. Vol 1 (1), hal.1-8.

Konstantinidou, E., Zisi, V., Katsarou, D., \& Michalopoulou, M. (2015). "Barriers and inhibitors of creativity in physical education". European Psychomotricity Journal, 7, 17-31. Retrieved from http://search.ebscohost.com/login.aspx?direct=true\&db=a9h\&AN=119793540\&site=ehostlive\&scope $=$ site

Kustandi, C \& Sutjipto, B. (2016). Media pembelajaran; manual dan digital. Bogor: Ghalia Indonesia.

Linacre, J.M. (2006). A User's guide to WINSTEPS Ministeps; Raschmodel Computer Program. Program Manual 3.73 .

Phillipson, Shane N. (2008). "The optimal achievement model and underachievement in Hong Kong: an application of the Rasch model". Psychology Science Quarterly, Volume 50 (2), pp. 147-172.

Prihana, Rani. (2017). Peningkatan Karakter Ksatria Melalui Pendidikan Karakter Berbasis Layanan Bimbingan Klasikal Dengan Pendekatan Experiential Learning. https://repository.usd.ac.id/9159/2/131114007_full.pdf diunduh pada tanggal 17 Oktober 2019.

Raka, Gede at. all. (2011). Pendidikan Karakter di Sekolah dari Gagasan ke Tindakan. Jakarta: Elex Media Komputindo.

Shearing, Lisabeth. M. (2008). "Family Functioning Scale Validation: A Rasch Analysis". Thesis. Universitiy of Illinois Chicago.

Stephens, Paul. (2014). "Undergraduate Student Satisfaction: Investigating The Measurement, Dimensionality, And Nature Of The Construct Using The Rasch Model". Theses and Dissertations-Educational Policy Studies and Evaluation. 25. https://uknowledge.uky.edu/epe_etds/25.

Subali, Bambang. (2011). "Pengukuran Kreativitas Keterampilan Proses Sains Dalam Konteks Assessment For Learning”. Cakrawala Pendidikan, No. 1

Sumintono \& Widhiarso. (2013). Aplikasi model rasch untuk penelitian ilmu-ilmu sosial. Cimahi : Trim Komunikata Publishing House.

Supriyadi, Edy. (2011). "Pendidikan Dan Penilaian Karakter Di Sekolah Menengah Kejuruan". Cakrawala Pendidikan, Mei 2011, Edisi Khusus Dies Natalis UNY. Hal.110-123.

Suprananto \& Kusaeri. (2012). Pengukuran dan penilaian pendidikan. Yogyakarta: Graha Ilmu.

Suryani, Yulinda Erma (2018). "Aplikasi Rasch Model dalam Mengevaluasi Intelligenz Structure Test". Psikohumaniora: Jurnal Penelitian Psikologi Vol 3 (1). 
Suwandi, Sarwiji. (2011). Model assesmen dalam pembelajaran. Surakarta: Yuma Pustaka \& FKIP UNS.

Triwati, Lilyana Aisyah. (2015). "Pengembangan Instrumen Penilaian Karakter Pada Pembelajaran Biologi di SMA Negeri 1 Demak". Skripsi. Fakultas Keguruan Ilmu Pengetahuan Alam, Universitas Negeri Surabaya.

Wainer \& Braun. (1998). Test Validity. Hilldale: Lawrence Earlbaum Asociates.

Zhou, J., Shen, J., Wang, X., Neber, H., \& Johji, I. (2013). "A cross-cultural comparison: Teachers' conceptualizations of creativity". Creativity Research Journal, 25 (3), 239-247. Doi: 10.1080/10400419.2012.730006 